\title{
THE GRAND DUCHY of LITHUANIA in EAST CENTRAL EUROPE or ONCE AGAIN ABOUT the LITHUANIAN- POLISH UNION
}

\author{
Jürate KLAUPIENE் \\ Lithuanian Institute of History
}

The Problem

The beginnings of Lithuanian statehood and the search for links with (western) Europe go back to the 13th century. Geographical position and the circumstances of historical development conditioned the specific nature of the "belated" Lithuanian state in the community of late-medieval Christian European states. We might term it a state of "being caught forever...", between East and West, between contradictory cultural and political forces and influences. From its very beginning the Lithuanian state had to fight for its right to existence, acknowledgement and integration into European political system.

Considering the place of the modern Republic of Lithuania on the geo-political scene of late-20th-century Europe, it is difficult to draw a clear line between history and politics and to delineate the sphere of 'pure' historical study. That becomes evident as soon as one becomes acquainted with the historical pattern of East Central Europe, being elaborated at present, and the image of Lithuania of the 13th-18th centuries in it.

The historiographical aspect of the problem is the subject of this paper. It is an attempt to discuss modern conceptions, dealing with the contribution of the Grand Duchy of Lithuania to the historical development of Europe and to throw some additional light on the formation and interpretation of certain peculiarities of East Central Europe.

The early-20th-century formation of the concept 'East Central Europe', the establishment of the boundaries of the region and its more accurate delineation have been widely debated by scholars at international congresses. ${ }^{1}$ Lithuanian historians did not actively participate in this discussion, since at that time professional history was still in the process of formation in this country. The Soviet occupation

'The most recent work, devoted to historiographical aspects of the formation of the notion 'East Central Europe' is East Central Europe in the Historiography of the Countries of the Region by J. Kloczowski. Lublin, 1995. 
of 1940, the post-war emigration of the overwhelming majority of the most competent historians, and the decades-long isolation of scholarship in Soviet Lithuania conditioned the politically orientated limitation of historical research, and cut Lithuanian historians off from modern developments in historical scholarship. The conceptions of Lithuanian historical research have not yet gained wider currency in the context of international discussions.

\section{Two Views of Modern Historiography}

The first question we shall deal with concerns 20th-century historians' interpretation of the geo-political position of the state, which appeared in East Central Europe in the 13th century and from the 14th century onwards was known as the Grand Duchy of Lithuania.

As Piotr Wandycz notes in the preface of his book, The Price of Freedom, the term 'East Central Europe' is arbitrary. It arose out of a need to define a region that is neither wholly Western nor Eastern, but represents a "middle zone" or "lands in between,"... The expression "East Central Europe" has been applied to the entire area between the Baltic, Adriatic, Aegean, and Black seas (flanked by ethnic German and Russian blocs), or some variations thereof, or to its "heartlands," to use Timothy Garton Ash's phrase, that is, Poland, Czechoslovakia, and Hungary... The frontiers of these states have fluctuated a good deal throughout history. They expanded and contracted, comprising at various times the present day Lithuania, Belorussia, and the Ukraine, as well as parts of Yugoslavia and Romania"?

Such is this pattern of East Central Europe, with its regional nuclei - Poland, Czechoslovakia and Hungary - and fringe nations and states; in the periphery stands Lithuania, her history understood and interpreted solely in the light of the history of the Polisch nucleus.

In his chronological review of the region's development in the late Middle Ages P. S. Wandycz writes; to summarize the chronology of the main political developments in East Central Europe over three centuries is no easy task. Perhaps a rough division into four periods may make it more intelligible. The first covered most of the thirteenth century and was characterized by fluctuations in Bohemia and Hungary, both ascending but suffering setbacks. Partial unification of divided Poland led to a dependence on Prague. Two new forces appeared in the region, the Teutonic Knights and the Habsburgs, with tremendous long-range consequences.

The second period encompassed most of the fourteenth century. This was the era of a remarkable parallelism in the three countries, all gaining power and importance. In Bohemia and Hungary this was the Golden Age'.

${ }^{2} \mathrm{P} . \mathrm{S}$. Wandycz. The Price of Freedom. A History of East Central Europe from the Middle Ages to the Present. London and Ncw York, 1992, 1.

${ }^{3}$ Ibid., 38 
In this region Lithuania is noticed by $\mathrm{P}$. S. Wandycz only in the third period of the late Middle Ages in the historical context of Poland: 'In Poland's case a dynastic union with Lithuania represented a turning point in the country's history and affected the balance of power in the region'. ${ }^{4}$

Thus, rather unexpectedly, Lithuania appears in East Central Europe at the end of the 14th century. 'Fourteenth-century Lithuania was a huge country, rich but underdeveloped, stretching from the Baltic almost to the Black Sea and comprising most of present-day Belorussia and the Ukraine. It was thus a dual state, Baltic and Slav, and after Jogaila accepted and introduced Christianity - the Wilno (Vilnius) bishopric was founded in 1387 - it was also a Catholic and Greek Orthodox conglomerate. In the west Lithuania faced the threat of the Teutonic Knights who, preaching conversion by sword, encroached on its territory. To stop them and to preserve the vast possessions in the east, to which the rising state of Muscovy aspired, a union with Poland had seemed the only alternative'.5 'But it did not mean that Jogaila's Lithuanian-Rus lands became incorporated into Poland, as the union act of Krewo seemed to imply. It was the dynasty and not Poland that continued to rule Lithuania. The Lithuanians - particularly Jogaila's cousin Vytautas (Vitold) who in the king's absence was governing the country - made it clear that they would not tolerate any Polish landowners, troops, or other forms of interference. ${ }^{6}$ Wandycz considers that, nevertheless, the process of Westernization and Polonization of Lithuanian nobility and gentry was taking place. Even though Lithuania did not resist the Polish cultural and linguistic influence, it produced quite a number of leaders, whose impact on the history of Poland was significant.

The dynastic union between Lithuania and Poland, established in 1386, became, in Wandycz's words, a real union in 1569. ${ }^{7}$ Dealing with the seventeenth-eighteenth-century history of the region, the author for some time treats Lithuania as a member of this (in his expression) unique Commonwealth. However, in the further analysis he more and more often passes over to the unequivocal term - Poland. The alliance of the two states is consistently identified only with one of them - Poland. In Wandycz's conception in the late 18th century there remains only 'the Polish state', one 'Polish nation', 'the divisions of Poland', 'the Polish question in Europe', etc.

Wandycz also maintains that the Grand Duchy of Lithuania,

${ }^{4}$ Ibid.

Inid., 41-42.

(Ibid., 42.

${ }^{7}$ Ibid., 49. 
having 'emerged' from being a remote province of East Central Europe due to the dynastic union with Poland, was polonized and practically became Poland. Thus, it is only in the framework of the Polish state that a place is alloted for the Grand Duchy of Lithuania, the nation which had created that state, and for all the other nations that had lived for centuries in that region of East Central Europe.

In his well known study Three Europes, dedicted to the memory of the Hungarian theoretician of social studies and politologist Istvan Bibo, the historian Jeno Szucs, in the formulation of the concept of European regions, continues Bibo's tradition by interpreting the social processes of East Central Europe in the light of the historical development of Hungary, Poland and Bohemia. In Szucs's concept, the history of the Grand Duchy of Lithuania is treated only as a constituent part of the history of Poland. The author sees only one PolishLithuanian kingdom of (the largest state in sixteenth-century Europe) with its entire 'political society' made up of the gentry of the Polish kingdom. In Szucs's opinion, this state disappeared namely as Poland after the divisions of 1772,1793 and $1795 .^{\circ}$

The German historians Klaus Zernack and Werner Conze, contributing to the development of this historiographic concept, associate the appearance of the Grand Duchy of Lithuania in the East Central European region also with the dynastic union of 1386.

In his attempt to model the history of Eastern Europe, Zernack distinguishes four main regions: East Central Europe, South East Europe, North East Europe and Russia." The Lithuanian state is located in East Central Europe, defined by the author as a region, which underwent changes in the course of history and the nucleus of which was the territories inhabited by Western Slavs. It is the area to the west of the line Elbe - Saale - Böhmerwald, and in the East it also comprises the lands of Eastern Slavs, which in cultural terms could be referred to as the zone of the Polish-Lithuanian influence of the Jogaila dynasty. ${ }^{10}$ Zernack concludes that this region, with its very particular social and cultural environment in the Middle Ages could be described as Baltic-West-Slavonic-Hungarian Europe, in which the process of Europeanization was conditioned by Western, rather than Byzantine culture. ${ }^{11}$

Discussing the historical epochs of Eastern Europe since the adoption of Christianity, Zernack does not pay any attention to either

${ }^{8} \mathrm{~J}$. Szucs. Vazlat Európa harom torteneti regiojarol. Bibo Emlckkonyv (In memoriam Istvan Bibo). Szamizdat. 1980. A separate official Hungarian cdition appeared in Budapest in 1983; in English - The Threc Historical Regions of Europc. In:Acta Historica Academiae Scientiarum Hungariae, t. 29 (1983), 131-184; in French - Les trois Europes. Paris, 1985; in Polish - Trzy Europy. Lublin, 1995.

"K. Zcrnack. Osteuropa. Eine Einführung in seine Geschichte. München, 1977.

"Ibid., 33.

"Ibid., 37. 
the baptism of 1251, and subsequent proclamation of Lithuania as kingdom, or to the pagan period of its history after 1263. The Grand Duchy of Lithuania appears on the historical horizon only in connection with its union with Poland in 1386. The author specially mentions three states - Poland-Lithuania, the Czech state (Bohemia) and Hungary as well as the significance of the Jogaila dynasty. ${ }^{12}$ In Zernack's conception the Grand Duchy of Lithuania also 'dissolves' in to the history of Poland by 1795 , i.e., the period of partitions, called the fifth historical epoch of Eastern Europe. In 1795 it is Poland that is partitioned.

Defining in an unfinished study, edited for publication by Zernack, ${ }^{13}$ the terms 'Central Europe' and 'East Central Europe', Werner Conze associates their history with political, religious and cultural processes and the changes, induced by them. The period of Lithuanian history prior to 1386 is described by the author in several short sentences to the effect that this state existed in a pressure zone of confrontation between Eastern and Western influences. The proper place of the Grand Duchy of Lithuania in this region was determined by the unions of 1386 and 1413 with Poland, a series of agreements crowned by actual union at Lublin. ${ }^{14}$ Defining the geographical boundaries of East Central Europe, the author discerns only two gentry 'nations' - the Poles and the Hungarians - which soon absorbed all the others: The duchy of Croatia was hungarized and that of Lithuania polonized. ${ }^{15}$

A regional pattern of this type is not an exception in historiography. The German historian Gotthold Rhode, investigating the change of the eastern Polish border - its movement to the East - from the beginning of its history until 1401 , is solving a far more complex problem of European history, namely the establishment of the eastern boundary of the Western Christian world and a validity of its equation with the eastern Polish border; his task is to present this area as a certain cultural interface and to display the influence of Polish expansion eastward. ${ }^{16}$ Already in the introduction to his study the author clearly distinguishes between Poland and the Grand Duchy of Lithuania and its constituent parts, present-day Lithuanian, Byelorussian and Ukrainian territories; emphasis is laid on the symbiosis of these three ethnic groups as one of the most important and significant problems of Eastern European history. ${ }^{17}$ The history of the L:ithuanian state, from its very origins, is presented alongside that of Poland and is treated as an inse-

'Ibid., 72.

${ }^{13}$ W. Conzc. Ostmitteleuropa. Von der Spätantik bis zum 18. Jahrhundert ed. K. Zernack. Munich, 1992.

${ }^{14}$ Ibid., 122-124.

${ }^{15}$ Ibid., 10.

${ }^{16} \mathrm{G}$. Rhodc. Die Ostgrenze Polens. Politische Entwicklung, kulturelle Bedeutung und geistige Auswirkung. I. Im Mittelalter bis zum .Jahre 1401. Köln-Graz, 1955.

${ }^{17}$ Ibid., 5. 
parable part of the history of the region, the development of which in the Middle Ages was under the influence of western Christianity. Having examined the major internal and external events in the life of Lithuania up to the year 1401, Rhode characterizes this country as an aggressive pagan force, which already before 1340 had started its activities in the eastern part of the region, bordering Halich-Volyn. ${ }^{18}$ Ascertaining a new status of Lithuanian statehood after Jogaila's establishment of the dynastic ties with Poland in 1386, Rhode emphatically maintains that, taking into account the extent of Lithuania's eastward expansion before 1386, it is impossible to speak about Lithuania's 'incorporation' into Poland. Still further, chronologically extending and developing this thesis, he comes to the conclusion that in the period between 1401 and 1569 there were two eastern boundaries of western Christendom - one would be the border of the common Polish-Lithuanian state, coinciding with the eastern border of Lithuania and the other - the border between the Polish kingdom and the Grand Duchy of Lithuania, much disputed by these two states. ${ }^{19}$

Two independent state - formations - Poland and Lithuania are also stressed by Percy Ernst Schramm. ${ }^{20}$ He quite clearly defines the place and the trends of change of thirteenth-century Lithuania in the region, emphasising its unique language, history, its own dynasty and aspirations; having met no resistance the Lithuanians imposed their rule in the Orthodox lands, inhabited by Byelorussians and Ukrainians. In 1386 Poland and Lithuania, ethnically different lands, were joined by a personal union. Evaluating this event in the light of history, Schramm stresses its positive aspect - pushing the European boundary line eastwards still further. ${ }^{21}$ Evaluating this situation in terms of Polish-Lithuanian relations, again does not treat them merely in the context of the history of Poland - on the contrary, the study contains a panorama of the most significant events of the history of Lithuania up to 1386 and draws the conclusion that the personal union per se did not reconcile all the contradictions between the two states and that the solution of that problem was not reached for a long time. This statement is supported by the comparison of the development of Lithuania and Poland between 1386 and the real union between the two states in Lublin in 1569 and by the discussion of Vytautas a attempts to be crowned king of Lithuania, and the reasons and consequences of his failure to achieve this.22

${ }^{18}$ Ibid., 134-135.

${ }^{10}$ Ibid., 340, 361.

${ }^{2}$ P. E. Schramm. Könige und Päpste. Gesammelte Aufsätze zur Geschichte des Mittelal-

ters. IV, 2, Stuttgart, 1971.

${ }^{21}$ Ibid., 551.

${ }^{22}$ Ibid., 548, 558, 593. 
Nevertheless, the prevailing tendency of modern historiography has been the modeling of east - central - European history in the light of the history of Poland, Bohemia and Hungary as nuclei. ${ }^{23}$ All of these works are not dealt with in this paper, and attention is drawn only recent research published in the United States, in order to illustrate the weaknesses of this model.

In her study ${ }^{24}$ Jean W. Sedlar, presenting her conception of the region, states that 'In a word, the era from 1000 to 1500 was in many respects the Golden Age for the nationalities of East Central Europe. At one time or another during these five centuries, Bulgaria, Serbia, Hungary, Poland, and Bohemia all were major states playing a leading role on the European stage. The Romanian Principalities of Walachia and Moldavia were less powerful, but still independent $\ldots . .^{25}$ In Sedlar's conception of the East Central European region there is no place for Lithuania as a state in the period under discussion. Clarifying when and which state of the region became a 'victim' of its more powerful neighbours, the author analyses the fate of Bulgaria, Serbia, Albania, Hungary, Bohemia and Poland. Of the latter she notes that 'Poland was carved up by Prussia, Russia, and Austria at the Partitions of 1772,1793 , and $1795{ }^{\prime}{ }^{26}$ In Sedlar's text Lithuania is dealt with merely in connection with the activities of the Teutonic and Livonian Orders and with the history of Poland. The author's understanding of medieval Lithuania and Lithuanians is surprising, since this country is identified with its only one - western part, namely Samogitia (Žemaitija). Explaining the reasons preventing the unification of the Teutonic and Livonian Orders, Sedlar indicates that '... between them lay Samogitia, a strip of land roughly equivalent to modern Lithuania. Early in the 14 th century Lithuania (Samogitia) was no more than a minor state along the Baltic Sea. Then under its Grand Duke Gedymin and his son Olgerd it was expanded to include much of what is now Belorus and large parts of Ukraine. In this way the rulers of Lithuania came to exercise a loose sovereignty over the vast but sparsely populated territories on Poland's eastern frontier. Most of this area was occupied by Eastern Slavs, speaking some variety of the language now known as Old Russian; only Samogitia was ethnically Lithuanian. ${ }^{27}$ After the 1386 dynastic union the history of the Grand Duchy of Lithuania is

${ }^{23}$ Sec: F. Graus, E. Bosl, F. Scibt, M.M. Postan, A. Gicysztor. Eastern and Western Europe in the Middle Ages. London, 1970; L.C. Tihany. A History of Middle Europe. From the Earliest Times to the Age of the World Wars. Now Brunswick, Now Jerscy, 1976; EastCentral Europe in Transition from the Fourteenth to the Seventeenth Century. cd. A. Mączak, H. Samsonowicz and P. Burke. Cambridge. 1985.

${ }^{24}$ J. W. Scdlar. East Central Europe in the Middle Ages. 100(1-1500. Seattle and London, 1994.

${ }^{25}$ Ibid., ix.

${ }^{26}$ Ibid., $\mathrm{x}$.

${ }^{27}$ Ibid., 21. 
presented as an integral part of the history of Poland. True, the author indicates that 'the joining of Poland and Lithuania under a single ruler by the Union of Krewo in 1385 similarly failed to produce a united Polish-Lithuanian state. Even after Grand Duke Jagiełło became king of Poland the next year, Lithuania under the rule of his cousin Witold behaved virtually as an independent country. It concluded treaties with the Teutonic Knights like a sovereign power and conducted its own wars. When Jagiełło died in 1434, his younger son Casimir became grand duke of Lithuania, while Vladislav, the elder, was elected king of Poland - a situation containing elements of a renewed separation. However, Vladislav's death without heirs in 1444 at the battle of Varna opened the way for Casimir IV to become the ruler of both realms. Poland and Lithuania remained linked by personal union until that king's death in 1492. Briefly the earlier division was restored when one of Casimir's sons was elected king of Poland and another became grand duke of Lithuania, but this arrangement proved to be impermanent. The link between the two realms continued until the Partitions of Poland in the late 18th century'. ${ }^{28}$

This image of the Grand Duchy of Lithuania, 'merged' with the Polish kingdom and its history since the late 14th century, was produced and became deeply ingrained in Western historiography by nineteenth - and twentieth - century Polish historians, who asserted that the Lithuanian state had been incorporated into the Polish kingdom by the Kreva act of union of Aug. 14, 1385. In the formation of the very concept of East Central Europe, this image was popularized by the Polish historian Oskar Halecki, known for his impressive style of writing. In his studies on the European regions and their history, ${ }^{29}$ prepared while working in the West, emphasis was placed in particular on two aspects of the history of the Grand Duchy of Lithuania: (1) the integration of the Lithuanian state with Poland began after the socalled Kreva union in 1385 and the transformation of the dynastic ties between Lithuania and Poland into a real federation began early (since 1401); (2) the exclusive role of Poland in the europeanization of the Grand Duchy of Lithuania and the ensuing spontaneous polonization of Lithuanian society. These two factors, according to Halecki, enabled the amalgamation of the two states into a single indivisible body politic, called Poland, which both geographically and historically occupied the principal place in East Central Europe next to the Danube states.

${ }^{2 x}$ Ibid., 282.

${ }^{29} \mathrm{O}$. Halccki. The Historical Role of Central-Eastern Europe (Rcprinted from the Annals of American Academy of Political and Social Science. Philadclphia, March, 1944); O. Halccki. The Limits and Divisions of European History. London and New York, 1950; O. Halccki. Borderlands of Western Civilization. A History of East Central Europe. Now York, 1952 
This kind of attitude to the historical place and importance of Lithuania in the region and the establishment of this viewpoint in twentieth-century European historiography was also influenced by the theory (at one time very popular in the West) of exceptional Polish democracy and cultural messianism, advocated the first half of the century by the Polish historian and philosopher Feliks Koneczny. ${ }^{30}$ Categorically stating that 'In the 15th-17th centuries no other European society possessed such a strong power of ideological infiltration as Poland..., ...in the 15th-century Europe one would not find another example showing the transmission of political ideas to other states, the example of this type was only Poland', Koneczny maintains that the beginning of this infiltration goes back to the late-fourteenth century relations with Lithuania. Concerning the results of the Polish cultural messianism in Lithuania, Konecznys' statements are quite explicit and outright: 'If Lithuanians had not adopted Polish culture, they would have been lost in the Russian one and ... today there would be no Lithuanian nation. Not a single Lithuanian peasant was polonized, because the Poles did not settle in Lithuania, while the Lithuanians have always been yielding to the Byelorussian expansion. But for the union with Poland, Russian pressure would have been stronger and more varied, affecting common people and the gentry, secular and religious life. Without the union with Poland Lithuania would have become "Orthodox", and in such a case could religious literature in Lithuanian and Lithuanian dictionaries, grammars and homiliaries have been produced? $?^{31}$

Was the 1386 dynastic union between Lithuania and Poland the only real beginning of the European history of the Grand Duchy of Lithuania?

This is the second question of the problem under discussion. Why is the above-presented pattern, distinguishing three east - central - European states as nuclei and their history as adequately representing the development of the entire region, controversial and open to debate?

If the history of the lands of the Grand Duchy of Lithuania and their peoples is treated only as a constituent part of the history of Poland, then there arises a question of the eastern border of east central - Europe both in the period before the late 14th century and in modern times - in the nineteenth and twentieth centuries. For a long

${ }^{30} \mathrm{~F}$. Koncczny. Polskie logos a ethos. Roztrzasanie o znaczeniu i celu Polski. T. 1-2. Poznan-Warszawa, 1921.

${ }^{31}$ Ibid., vol. 2, 77-78, 132. 
time in a grey pulsating "no-man's" land there appears a large territory of Europe, in which a unique social and cultural pattern of a multinational and multi-faith society and state has been developing since the 13th century. In the background of this pattern, epitomized in the Grand Duchy of Lithuania and comprising a mixture of tribal Baltic and Slavic lands and Christian traditions, spreading from the West, complicated processes of adopting and transforming new values were taking place.

It is also noteworthy that already before the establishment of the dynastic ties between Lithuania and Poland in 1386 there appeared an ever increasing Western tendency in the development of the Lithuanian state model. This is attested by the 1251 Catholic baptism of the Lithuanian ruler Mindaugas, by the establishment of a diocese, directly subordinate to the Pope, by the coronation of Mindaugas in 1253 and correspondingly Lithuania's becoming a kingdom. The 13thcentury baptism did not survive, and Mindaugas himself was assasinated in a conspiracy. Lithuania - the nucleus of the Grand Duchy of Lithuania - remained pagan until the end of the 14th century; neither was its royal status preserved - the country remained a duchy. Nevertheless, in the period before Jogaila's baptism of 1387 there were quite a number of attempts on the part of the Lithuanian grand dukes to accept Chrisitianity. All these attempts were orientated towards the West, towards the Catholic form of Christianity despite the fact that the Grand Duchy was permanently at war in the West with the Teutonic Order, at the same time expanding territorially eastwards and incorporating ever greater numbers of the Orthodox population.

In the context of these deliberations it is worthwhile returning to Rhode's study. Reviewing the new situation in the region after Mindaugas' acceptance of Christianity and the Polish missionary endeavours among the Lithuanians and Yatvingians in the 13th century, the author emphasizes the fact that the initiative of adopting Christianity undoubtedly belonged to Mindaugas, and the question is only what was the stimulus to that action of the ruler..$^{32}$

No doubt, one could argue with Rhode's premises, statements and arguments. Disregarding the endeavours of the pagan Lithuanian state to become Christian in the context of the historical development of the region up to the end of the 14th century leads to a limited solution of the problem.

The presence of these endeavours is also attested by the western attempts of the Gediminids to become Christianized during the

${ }^{32} \mathrm{G}$. Rhode. Die Ostgrenze Polens. 147.

${ }^{33}$ The most up-to-datc litcrature on this issuc: S. C. Rowell. Lithuania Ascending. A Pagan Empire within East-Central Europe, 1295-1345. Cambridgc, 1994; A. Nikžentaitis. Nuo Daumanto iki Gedimino. Ikikrikščioniškosios Lietuvos visuomenès bruožai (From Daumantas until Gediminas. Prc-Christian fcaturcs of Lithuanian socicty). Klaipćda, 1996. 
rule of Gediminas and Algirdas in the fourteenth century. ${ }^{33}$ These actions are indicative of the orientation of the Lithuanian ruling dynasty. Before his marriage, baptism and ascending the throne of the Catholic Polish kingdom the Grand Duke of Lithuania Jogaila had an alternative of baptism, disregarded by Wandycz. Jogaila's other alternative was the Orthodox Church and the post of the duke of Muscovy, which could have been obtained in the same way by the dynastic ties of marriage. Nevertheless Jogaila ignored the ethnic composition of the population of his patrimony - the Grand Duchy of Lithuania - and the contacts with the Orthodox milieu of his mother Duchess Juliona and their pressure and preferred Catholicism and the throne of the Polish kingdom. Could this development of events be accounted for merely by the interests of the politicians of Little Poland to place Jogaila on the Polish throne? In our opinion that would be an oversimplified answer to the question.

The reasons for Jogaila's choice should be discussed in the context of the entire development of the political Gediminid orientation in the 14th century. The ruling dynasty, freely extending its territory eastwards, at the same time was aiming at the integration into the political, ideological and cultural sphere of east - central Europe.

Was the situation really like that? Is it not common knowledge that the Gediminid dukes, sent to the Russian lands, governed by the Grand Duchy of Lithuania, used to marry local women, accept the Orthodox faith and become "Russianized?" This kind of assertion is not new - conversely, it has a long historiographic tradition. Its historiophilosophical substantiation can be found in the above mentioned Koneczny's arguments, relating to the exceptional quality of Polish civilization. In his categorical statements that it was Polish civilization that saved Lithuania from utter Russification and Orthodoxation, the author stresses that in the second half of the foueteenth century the area of the Orthodox Church spread extensively, and the Gediminid dynasty, penetrating further into the Russian lands, did not bring anything Lithuanian there, but became Russified itself. Algirdas' wives were Russian, all his sons used the Russian language, they baptized themselves in Russian Orthodox churches and Algirdas himself did that when he was on his deathbed. His successor, Jogaila, was prepared to do the same already at the beginning of his career and to rely on Russia alone, considering Lithuania a lost country, indefensible against the attacks of the Teutonic Order. The situation changed in the most unbelievable way when Jogaila was invited to the Polish throne. ${ }^{34}$

There would be no need to comment the statements, expressed by Koneczny in 1927, if they had not been reiterated by modern sholarship at the end of the century. The point is, that the historical

${ }^{34} \mathrm{~F}$. Koneczny. Polska między Wschodem a Zachodem (Poland between the East and the West). Lublin, 1996, 23. (This text was first published in 1927). 
development of the Grand Duchy of Lithuania contradicts the statements about the Gediminid dynasty being Russified and practising the Orthodox faith in the 14th century. There are no sources, supporting the statement, which has been uncritically re-written from one work into another for quite a number of years, about Algirdas' adopting the Orthodox faith. On the contrary, the known sources show that Grand Duke Algirdas was cremated on his funeral pyre according to pagan custom. There are no reliable sources, attesting to the acceptance of the Orthodox rite by any other grand dukes of Lithuania. This form of baptism was usually practised by those Gediminids, who were sent to govern the newly annexed Russian lands, but they were not independent rulers, they only executed the policy of the central power, acting on behalf of the grand dukes.

Western orientation was the basis of the policy of Jogaila's cousin Vytautas in his efforts to obtain an independent status for both the Grand Duke and the Grand Duchy of Lithuania. These facts are well known. For the advancement of his policy Vytautas sought the aid even of the Teutonic Order - the enemy of the Lithuanian state and from Emperor Sigismund he managed to achieve recognition and the right to be crowned king of Lithuania. The reforms introduced on the initiative of Vytautas, updated the contemporary social and administrative system of the Grand Duchy of Lithuania, added new impetus to the further development of the Western tendency both in the central ethnic Lithuanian lands and in peripheral Slavic territories. By the middle of the 15 th century in these territories there developed a society, whose organizational principles significantly differed from those of the Russian lands of Muscovy.

Western orientation, introduced and established by the Gediminids in the 15 th century, was taken over and developed subsequently by the evolving political élite of the Grand Duchy of Lithuania either independently or exploiting the dynastic ties of the Gediminids and Jagellonians with Poland.

In the 16 th century the results of this orientation became manifest in the form of the religious-cultural movement developed by the Protestants in the Grand Duchy of Lithuania, the preparation and publication of Lithuanian books and the specific cultural trends in the Slavic lands of the state. In the sixteenth century European nations began looking for their historical roots. When the ideology of Sarmatianism was spreading in Poland, a Western theory of the Roman origin of the Lithuanians was created and readily accepted by the population of the Grand Duchy of Lithuania. Treating the Grand Duchy of Lithuania only as "amalgamated" with Poland since 1386 and maintaining contacts with European culture only through Poland, it would be difficult to account for the phenomenon of the Roman origin of the Lithuanians. 
It would also be impossible to ignore the fact that the multinational gentry of the Grand Duchy of Lithuania developed into a "political nation" on the ideological basis of the Lithuanian statehood instead of joining the "political nation" of Poland. The Lithuanian historian Alvydas Nikžentaitis describes this process in the following way: 'The more rapid pace of the development of the Lithuanian political nation is easily noticeable in the late 14 th century. That was not conditioned by the conversion of Lithuania, as one might presume, but by the formation of an independent estate of the gentry. The gentry became the principal proponents of nationalism in Lithuania'. ${ }^{35}$ And he further adds that 'the Lithuanian political nation was not homogeneous. As in other countries, it comprised representatives of nobility. Ethnically it consisted of Lithuanian and Samogitian nobility, and later on, from the second half of the 15th century the Russian nobles of the Grand Duchy of Lithuania belonged to it. One of the most remarkable manifestations of their presence in the Lithuanian political nation is the 1501 peace treaty of Melnik, in the preamble of which the representatives of the Russian lands of the Lithuanian state declared: 'Nos Lituani....'36

The enumeration of such facts, attesting the separateness of the Grand Duchy of Lithuania from the Polish kingdom, can be carried on up to the end of the eighteenth th century, when the declaration of the Constitution of 3 May 1791 provoked the reaction of the Grand Duchy of Lithuania, again proclaiming its sovereignty. On 20 May 1791 the Lithuanian representatives after long debates with the Polish side reached their main aim - "Zaręczenie obojga narodów" (Law on mutual guarantees of the Two Nations). By this Act, the Grand Duchy of Lithuania was recognized as a second member, equal to Poland, in the dual Commonwealth. The Act of "Guarantees" was equated with the 1569 Act of the Lublin Union and provision was made to treat it as a part of pacta conventa. The struggle for the adoption of this document indicates that, even in the period of partitions in the late 18th century, there were political forces, which did not identify themselves with Poland and defended the statehood and sovereignty of the Grand Duchy of Lithuania at national level. That also shows that in east - central Europe side by side with Poland there existed the Grand Duchy of Lithuania with its own interests and aspirations. These facts are well known to those researching the history of Poland and Lithuania, however, they are not always taken into account in modelling the concept of east - central Europe. The results of such "forgetfulness" are very well illustrated by Koneczny's interpretation of the final stage of the history of the Lithuanian and Polish unions. Summa-

${ }^{35}$ A. Nikžcntaitis. Nuo Daumanto iki Gedimino, p. 88.

${ }^{36}$ Ibid., 88 . 
rising his reasoning about the Lublin Union of 1569, he writes; 'when spiritual and political renaissance begam and Polish law began to develop anew, the inhabitants of the Grand Duchy themselves noticed how outdated was their relationship with the Crown was. And then, at one stroke a rapid leap was made over 222 years and in 1791, at the request of the Lithuanians, the political separateness of the Grand Duchy was abolished; the most elementary amalgamation into the Crown took place. The Four-year Diet of the good old days, the Great Diet abolished the union and unified Poland and Lithuania into one completely homogeneous state. At that time the Lithuanians themselves declared that that merger was in the interests of Lithuania. Such is a historical fact. Could there be a greater triumph for the political ideas of Poland?', asks Koneczny before going over to analyse twentiethcentury history. ${ }^{37}$

An historio-philosophical treatise of the 1930s and the theories of its author would not be worth a mention, if similar ideas and interpretations were not viable repeated in scholarship at the end of the century.

Problems such as these are topical, because in this social symbiotic medium of the Grand Duchy of Lithuania the westwards-orientated traditions of statehood and civilization of three present-day nations - Lithuanians, Byelorussians and Ukrainians have been developing for 500 years. To a certain extent the influence of these ideas was also felt in Livonia, inhabited by the ancestors of today's Latvians and Estonians. In the 19th century, the development of all these modern nations was taking place in the framework of the Russian Empire. Historical interpretation of Lithuania in the thirteenth-eighteenth centuries in its turn conditions the historical interpretation of the entire region.

This kind of attitude towards the Grand Duchy of Lithuania in no way rejects the existence of influences. In the society of the Duchy they were evident in the Eastern traditions, spreading through the old Russian lands; on the other hand, Western traditions came mostly through Poland and some other channels. However neither exaggerating nor underrating any one of these influences can lead to the establishment of the proper place of the modern nations in the region in the 19 th and 20th centuries and respectively the very process of the formation of the national states of Lithuania, Latvia and Estonia in 1918 as well as the their development up to the present day can become clearer and more tangible. After the collapse of the Soviet Union, on the geopolitical map of Europe there appeared independent sovereign states of Lithuania, Latvia, Estonia, Byelorussia and Ukraine, the historical roots of which go back to the Grand Duchy of Lithuania and its sphere of influence in the thirteenth-eighteenth centuries. Thus, the

${ }^{37}$ F. Koncczny. Polskie logos a ethos, t. 2, 137. 
eastern frontier of the east - central European region will be no more "pulsating" and controversial, and the political, cultural and social Western orientation of the present-day Lithuania will be more coherent and more comprehensible.

In the context of the above-presented arguments there again arises the issue of the so-called union of Krèva. Up to the present day historians have been variously referring to the ties between Poland and Lithuania - the dynastic union, the personal union, the federal union and the incorporate union. Each of these terms is not identical and unequivocal legally. The question is which of the terms is more suitable for the definition of the ties between the two states. Was their essence the dynastic marriage of Jogaila from the Gediminids and Jadwiga from the Angevins? Was it the Kreva act Aug. 14, 1385, proclaimed before the marriage, that served the legal basis for these ties?

If the marriage is considered dynastic on the basis of the union of 1386, then there arises the question of the difference between the Lithuanian-Polish union and other dynastic unions of medieval Europe. If the basis of the union is the act of Kreva, designed before the marriage, then the situation would be different and other questions would arise. The first question is the essence of the act in terms of medieval law. Scholarship is full of all kinds of interpretations: it was an act, incorporating the Lithuanian state into the Polish state, an act, putting an end to the Grand Duchy of Lithuania as a state, etc. On the other hand, there are legal interpretations, stating that it was Jogaila's premarital promise of a preliminary nature, given at the beginning of the negotiations on the conditions of his ascending the throne of Poland. There are suppositions concerning the presence of one more document, confirming the act of Kreva. However, such a document has never been found. Many studies have been published on this problem, and it is not the task of this paper to review them more extensively. Attention should be paid to the fact that in recent sholarship the number of writers, categorically asserting the incorporation of Lithuania into the Polish state in 1385, is decreasing. The change in the attitude is conditioned by the difficulties which adherents of this theory have in answering many questions, familiar to historians: why such an important document is not mentioned in contemporary sources; why it was never used by the politicians in solving complex political problems of the two states; why such homage acts of Lithuanian dukes were necessary; why the act of Kreva is referred to neither in Lithuanian nor in Polish historical tradition; why this important document was kept in the archive of the Kraków chapter and not in the archive of the Polish kingdom; why it was not used by the 15th-century Polish historian Jan Długosz, the canon of the same chapter, etc., etc.

If the Kreva act of 1385 was presented only during the negotiations as a preliminary document and therefore was not deposited in 
the state archive, was not used in the political life of the two countries, did not find its way into the historical tradition, remained unnoticed for nearly 500 years and was discovered and made popular through various interpretations by the historians of the 19th and 20th centuries, then the dynastic ties, established in the last quarter of the 14th century, would be devoid of any legal incorporation content. Would that be sufficient grounds for modelling the European image of the Grand Duchy of Lithuania, "dissolved" in the history of Poland?

The paper could be ended on an optimistic note, taking into account those new trends, noticeable in the international activity of the historians of the east - central European region after 1989. These positive changes are perhaps best defined by a most active organizer of cooperation and frank discussion, head of the East Central European Institute of Lublin, Jerzy Kłoczowski: 'The independence of Poland, Czechoslovakia and Hungary in 1989, to be followed by other countries, presented historians with new tasks and challenges. In the subject that interests us the question arises: How did the new situation affect the international cooperation of historians of the region and the treatment of national histories in the larger framework of East Central Europe and Europe tout court?; and he continues, indicating that in 1990 saw '... the first gathering of outstanding representatives of four nations: Belorus, Lithuania, Poland and the Ukraine. The convention was attended mainly by historians, including émigré ones, and historical topics took to the fore in both official and private discussions. The most important result of the convention was a decision to maintain an ongoing dialogue in the field of east - central European history. ... We hope that the advanced studies on the history of Belorus, Lithuania, Poland and the Ukraine, edited together by scholars from the four countries, will become a model for the remaining countries and areas of East Central Europe'. ${ }^{38}$ It is to be hoped that the history of the Polish-Lithuanian unions will also be looked at from new angles.

${ }^{38} \mathrm{~J}$. Kłoczowski. East Central Europe in the Historiography of the Countries of the Region. Lublin, 1995, 47, 52-54. 